\title{
Yield and nutritional quality of aeroponically cultivated basil as affected by the available root-zone volume
}

\author{
Georgios Salachas ${ }^{\star 1}$, Dimitrios Savvas ${ }^{2}$, Konstantina Argyropoulou', Petros Andrea Tarantillis ${ }^{3}$, \\ Georgios Kapotis ${ }^{1}$
}

${ }^{1}$ Department of Agricultural Technology, Laboratory of Plant Physiology and Nutrition, T.E.I. of Western Greece, Amaliada, Theodoropoulou st., 27200, Greece; ' 2 Department of Crop Science, Laboratory of Vegetable Crops, Agricultural University of Athens, 75 lera Odos, Athens 118 55, Greece;

${ }^{3}$ Department of Food Science and Human Nutrition, Laboratory of Chemistry, Agricultural University of Athens, 75 lera Odos, Athens 11855 , Greece

\section{A B S T R A C T}

\begin{abstract}
This study investigates the effect of the available root zone volume on yield and quality characteristics of aeroponically cultivated sweet basil (Ocimum basilicum, L.) plants. Growth and photosynthesis were also evaluated. At a fully automated glasshouse aeroponic growing system, plants were cultivated in canals with $10 \mathrm{~m}$ length, $0.67 \mathrm{~m}$ width for depths: of $0.15 \mathrm{~m}, 0.30 \mathrm{~m}$ and $0.70 \mathrm{~m}$. Plants cultivated in growing canals with the lower depths $0.15 \mathrm{~m}$ and $0.30 \mathrm{~m}$, gave increased dry biomass production; plant height; root length; leaves per plant; total chlorophyll content; net photosynthesis rate; transpiration rate and stomatal conductance, in comparison with plants cultivated in canals with the maximum depth of $0.70 \mathrm{~m}$. In contrast, plants cultivated in $0.70 \mathrm{~m}$ depth canals showed statistically increased root dry biomass production. No significant differences were determined for the total leaf phenolics content. Essential oil content was determined at $0.83 \%$, $0.79 \%$ and $0.80 \%(\mathrm{v} / \mathrm{w})$ for the three growing canals $(0.15 \mathrm{~m}, 0.30 \mathrm{~m}$ and $0.70 \mathrm{~m}$ depth) respectively, characterized by high linalool content $(63.85 \%$, $67.02 \%$ and $66.58 \%$ respectively).Our results shown that basil plants grown aeroponically are of superior nutritional quality characteristics.
\end{abstract}

Keywords: Aeroponics; Sweet basil; Plant yield; Nutrition quality; Root- zone volume

\section{INTRODUCTION}

Sweet basil (Ocimum basilicum L.), is a popular culinary herb (family of Lamiaceae), native to tropical Asia. Nowadays cultivated world-wide under natural and greenhouse conditions (Putievsky and Galambosi, 1999; Makri and Kintzios, 2008). It is a very important medicinal plant and spice for cooking and is marketed fresh, dried or frozen (Loughrin and Kasperbauer, 2001). It is also used in medical treatments for headaches, coughs, worms, stomach-ache and kidney malfunctions (Simon et al., 1990), against insect bites (Waltz, 1996). Many cultivars and varieties are used and some are cultivated especially for the Italian manufacture of pesto (Vieira and Simon, 2006). Furthermore, the essential oil from sweet basil used in food, perfumery and medical industry (Simon et al., 1990; Grayer et al., 1996, Stojiljković et al., 2015).

The hydroponic cultivation of basil is in the focus of efforts to improve the product yield and quality (Kiferle et al., 2013; Maboko and Du Plooy, 2013; Roosta, 2014, Walters and
Currey, 2015). On the other hand there is little information on the aeroponic cultivation of herbs. Aeroponics is a method in which the roots of the plant are growing in the air, with the nutrients sprayed as a fine mist of a complete nutrient solution (Zobel et al., 1976). It has been used very successfully in many cases of plant growth (Zobel et al., 1976; Peterson and Krueger, 1988; Burgess et al., 1998). Advantages of the aeroponic systems are the optimum root aeration (Soffer and Burger, 1988), the limited amount of water and nutrient used, the nutrient solution recirculation the online monitoring of nutrients and $\mathrm{pH}$, all resulting in an increased yield (Farran and Mingo-Castel, 2006). Plants cultivated aeroponically had a higher biomass yield and total phenolics and flavonoid content and antioxidant properties compared to plants grown in the soil (Chandra et al. (2014).

Under aeroponic growth conditions, the good aeration of the roots (the main organ involved in water and mineral uptake), is the most important factor for the growth of plants. In aeroponics, plants are totally suspended in the air, giving their root system access to $100 \%$ of the available

\footnotetext{
${ }^{*}$ Corresponding author:

Georgios Salachas, Department of Agricultural Technology, Laboratory of Plant Physiology and Nutrition, Technological Educational Institute of Western Greece, Campus Amaliada, 27200, Patras, Greece. E-mail: gsal@teimes.gr 
air oxygen, promoting thus root metabolism and plant growth (Chiipanthenga et al., 2012), in comparison with hydroponic and soil cultivations. This study investigated the impact of the available root-zone volume on the yield and nutritional quality of sweet basil plants grown aeroponically.

\section{MATERIALS AND METHODS}

The experiment was carried out at a fully automated aeroponic greenhouse farm $\left(500 \mathrm{~m}^{2}\right)$, located at Mesolonghi (lat. $38^{\circ} 59^{\prime} \mathrm{N}$, long. $22^{\circ} 36^{\prime} \mathrm{E}$ ), near the coastal area of Western Greece. The detached greenhouse was situated in the north-south direction. The closed recirculated aeroponic system consisted of three growing canals ( $x$ three replications). The growing canals are made of polystyrene insulated material of rectangular section, with constant length $10 \mathrm{~m}$, width $0.67 \mathrm{~m}$ and depths of $0.15,0.30$ and $0.70 \mathrm{~m}$. The canals were covered with polystyrene panels with three parallel holes for holding the plants. Totally, 450 sweet basil seed plants of about $10 \mathrm{~cm}$ height each transplanted (after washing the roots in order to remove the soil) in the aeroponic growing canals. A high pressure irrigation system with two parallel pipes containing aeroponic sprayers was installed inside the structures in the bottom of the canals. The roots of the plants were sprayed by the nutrient solution for $25 \mathrm{sec}$ every $5 \mathrm{~min}$. The whole system was controlled electronically. Plants were grown under conditions. The root zone was automatically set to $20^{\circ} \mathrm{C}$. The dry biomass content, the root length, the shoot high and the number of leaves per plant were measured every 10 days during the growing period. The rate of net photosynthesis, the rate of transpiration, the stomatal conductance, the chlorophyll content and the total phenolics content of roots and leaves were also determined at the end of the growing period.

\section{Nutrient solution}

The nutrient solution used for irrigation had the following macronutrient composition, $(\mathrm{mM}): \mathrm{K}^{+}, 6.5$; $\mathrm{Ca}^{2+}, 3 ; \mathrm{Mg}^{2+}, 0.9 ; \mathrm{NO}_{3}-6.75 ; \mathrm{NH}_{4}^{+}, 0.36 ; \mathrm{H}_{2} \mathrm{PO}_{4}^{-}$, 1.6 and micronutrient $(\mu \mathrm{M}): \mathrm{Fe}^{2+}, 30 ; \mathrm{Mn}^{2+}, 5 ; \mathrm{Zn}^{2+}, 4$; $\mathrm{Cu}^{2+}, 0.75 ; \mathrm{B}^{+3}, 30 ; \mathrm{Mo}^{+6}, 0.53 \mathrm{pH}$ was adjusted to 5.6 by the use of $\mathrm{HNO}_{3}$ - and the electrical conductivity was kept at $1.70 \mathrm{dS} \mathrm{m} \mathrm{m}^{-1}$. The temperature of the nutrient solution was kept at $20^{\circ} \mathrm{C}$ automatically. Preparation of the nutrient solution, adjustment of $\mathrm{pH}$ and electrical conductivity were controlled electronically.

\section{Gas exchange measurements}

Gas exchange measurements were conducted for seven fully expanded, mature leaves per experimental set of conditions using the LCI Portable Photosynthesis System (ADC, BioScientific Ltd., England). In this system, $\mathrm{CO}_{2}$ is determined by an infrared gas analyzer and $\mathrm{H}_{2} \mathrm{O}$ is recorded with two laser trimmed humidity sensors. Experimental measurements included net photosynthesis rate $(\mu \mathrm{mol}$ $\left.\mathrm{CO}_{2} \mathrm{~m}^{-2} \mathrm{~s}^{-1}\right)$, transpiration rate $\left(\mathrm{mmol} \mathrm{m}^{-2} \mathrm{~s}^{-1}\right)$ and stomatal conductance for $\mathrm{CO}_{2}$ diffusion $\left(\mathrm{mol} \mathrm{H}_{2} \mathrm{O} \mathrm{m}^{-2} \mathrm{~s}^{-1}\right)$. All measurements were performed in fully expanded leaves of the same physiological age, at the same daytime and under identical natural light (incident photon flux density on the leaf surface $\approx 1000 \mu \mathrm{mol} \mathrm{m} \mathrm{m}^{-1}$ ) and temperature conditions (leaf surface temperature was between $25^{\circ} \mathrm{C}$ and $\left.32^{\circ} \mathrm{C}\right)$.

\section{Chlorophyll content}

Three discs $(0.9 \mathrm{~cm}$ in diameter) from each leaf (first fully expanded leaf) were incubated with $3 \mathrm{ml}$ of dimethylsulphoxide (DMSO $99.5 \%$ or 14.8 M; Sigma Chemical Co.) in a glass tube at $65^{\circ} \mathrm{C}$ for $60 \mathrm{~min}$ until the tissue became colorless (Shinano et al., 1996). The absorbances at $665 \mathrm{~nm}$ for chlorophyll a and $648 \mathrm{~nm}$ for chlorophyll b were determined. The chlorophyll content was evaluated according to Lichtenthaler and Wellburn (1983), using the equations:

$$
\begin{aligned}
& \text { Chlorophyll a, Chla }=14,85 \mathrm{xA}_{665}-5,14 \mathrm{xA}_{648}(\mathrm{mg} \mathrm{Chla} / \mathrm{ml}) \\
& \text { Chlorophyll b, Chla }=25,4 \mathrm{xA}_{648}-7,36 \mathrm{xA}_{665}(\mathrm{mg} \mathrm{Chlb} / \mathrm{ml})
\end{aligned}
$$

Total chlorophyll concentration $(\mathrm{a}+\mathrm{b}), \mathrm{Chl}(\mathrm{a}+\mathrm{b})=$ Chla + Chlb (mg Chl/ml).

\section{Total phenolics}

Fresh leafs of basil $(1 \mathrm{~g})$ were homogenized in an UltraTurrax in $10 \mathrm{ml}$ solution of methanol: deionized water: formic acid in proportion $50 \mathrm{ml}: 48.5 \mathrm{ml}: 1.5 \mathrm{ml}$ respectively for $100 \mathrm{ml}$ solution (Mazza et al., 1999). The homogenate was centrifuged in a cooled centrifuge Centra MP4R (IEC, USA) at $10.000 \mathrm{~g}$ for $10 \mathrm{~min}$ at $4^{\circ} \mathrm{C}$ and the supernatant was used for the determination of phenolics. The absorbance of the supernatant was measured at $280 \mathrm{~nm}$. The content of total phenolics was determined using a gallic acid standard curve and was expressed as $\mu \mathrm{gr}$ GAE/gr F.W.

\section{Isolation and analysis of the essential oils}

When basil plants reached full bloom, harvested samples of fresh leaves, stems and flowers, were cut in small pieces and submitted to hydro distillation with a Clevenger-type apparatus for $4 \mathrm{~h}$ (1.500 $\mathrm{g}$ with 6 lit of water). The essential oils were collected, dried under anhydrous sodium sulfate and stored in dark glass bottles at $4^{\circ} \mathrm{C}$ until further analysis. Essential oils yield (\%) was calculated as per $100 \mathrm{~g}$ of dry material.

The qualitative and quantitative analysis of the essential oils was performed using a Hewlett Packard 5890 II GC, equipped with a HP-5MS (crosslinked 5\% PH ME siloxane) capillary column ( $30 \mathrm{~m}, 0.25 \mathrm{~mm}$ i.d., $0.25 \mathrm{~mm}$ 
film thickness) and a mass spectrometer 5972 as detector. The carrier gas was helium, (rate $1 \mathrm{ml} / \mathrm{min}$ ). The initial column temperature was $60^{\circ} \mathrm{C}$ and gradually increased to $250^{\circ} \mathrm{C}$ at a rate of $3{ }^{\circ} \mathrm{C} / \mathrm{min}$. The total time of the method was $63.33 \mathrm{~min}$. For GC-MS detection, an electron ionization system was used with ionization energy of 70 Ev. Injector and detector (MS transfer line) temperatures were set at $220^{\circ} \mathrm{C}$ and $290^{\circ} \mathrm{C}$, respectively. Diluted samples of $0.1 \mathrm{ml}$ (the solvent was acetone of $99.8 \%$ purity) were injected manually and split less. Chromatographic peaks were identified by retention times and mass spectra of authentic compounds when available.

\section{Statistical data analysis}

Mean values of all treatments were compared by one-way ANOVA test and significant differences were determined using Duncan's test $(\mathrm{p}<0.05)$. All data were analyzed using the SPSS 17.0 program for Windows.

\section{RESULTS AND DISCUSSION}

\section{Growth measurements}

From the beginning of the growing season and up to the first month, there were small but not statistically important differences in the mean shoot and root dry biomass content (Fig. 1, 2). After the first month, the shoot dry weight of the plants cultivated into canals with depth 15 and $30 \mathrm{~cm}$ significantly increased in comparison to plants cultivated into canals of $70 \mathrm{~cm}$ depth (Fig. 1). At the end of the growing period, the shoot dry weight of the plants in canals with depth of 15 and $30 \mathrm{~cm}$ was doubled compared to that plants grown in $70 \mathrm{~cm}$ depth. In contrast, the root dry biomass content of plants grown in $70 \mathrm{~cm}$ depth canals increased significantly, in comparison with plants grown in canals with depth 15 and 30cm (Fig. 2).

Plants from the third week and from lower depth (15 and $30 \mathrm{~cm}$ ) growing canals became higher than in $70 \mathrm{~cm}$ depth canals (Fig. 3). In contrast, after the first month of growing season, roots from lower depth were significantly shorter in comparison to roots from $70 \mathrm{~cm}$ depth canals (Fig. 4). The number of leaves per basil plant significantly increased for lower depth $(15$ and $30 \mathrm{~cm})$ growing canals than in $70 \mathrm{~cm}$ depth canals (data not shown).

The above results showed that the available root zone volume was essential for the aeroponic growth of plants. Basil plants cultivated aeroponically in the lower depth $(15$ and $30 \mathrm{~cm})$ canals had better growth characteristics as shown by increased shoot height, higher number of leaves per plant and increased shoot dry biomass content. In comparison, plants cultivated in deeper, $(70 \mathrm{~cm})$ canals, had. lower shoot height, lower number of leaves per plant and lower shoot biomass content, possibly due to inadequate

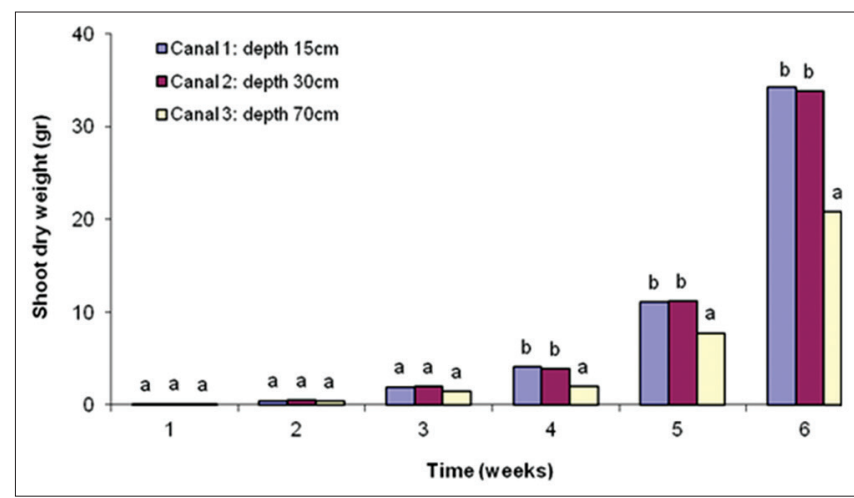

Fig 1. Mean shoot dry biomass content of aeroponically cultivated basil plants during cultivation season, in relation to the available root-zone volume.

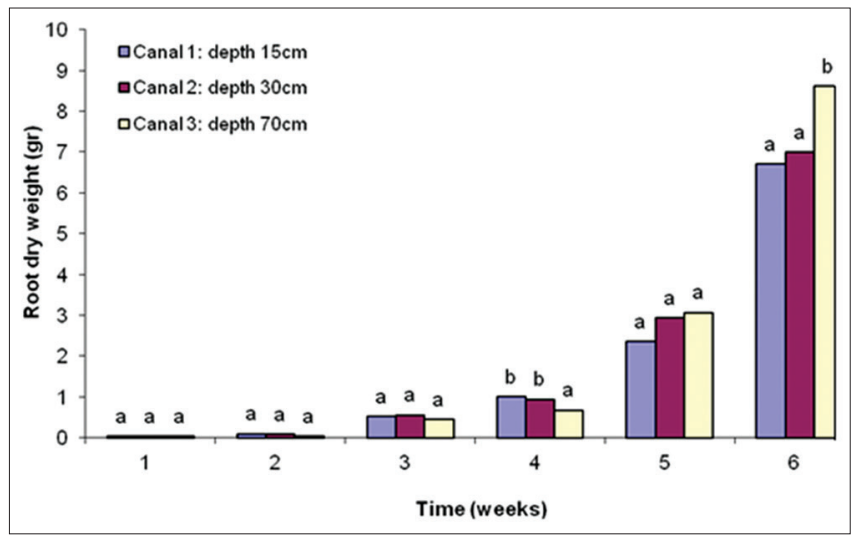

Fig 2. Mean root dry biomass content of aeroponically cultivated basil plants during cultivation season, in relation to the available root-zone volume

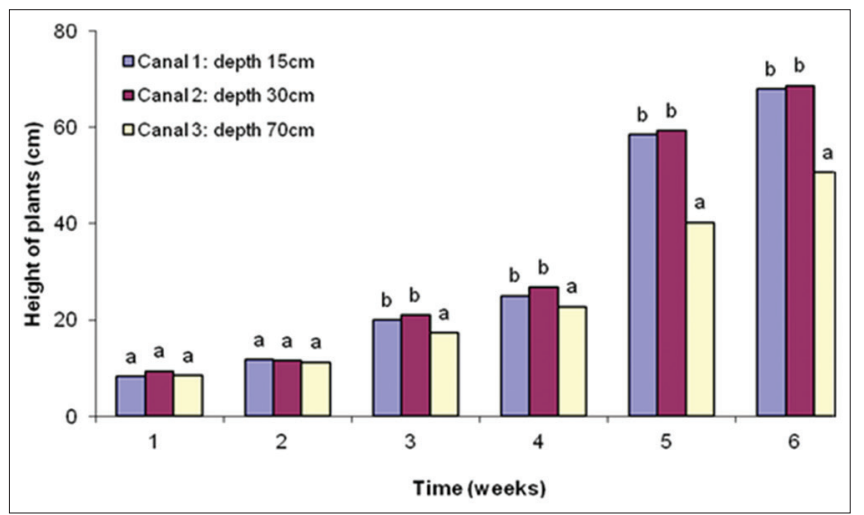

Fig 3. Mean shoot heigth of aeroponically cultivated basil plants during cultivation season, in relation to the available root-zone volume

nutrition availability and absorption. By misting or injecting the nutrient solution under high pressure directly and closer onto the surface of the roots $(15$ to $30 \mathrm{~cm}$ ), the plants were enforced profoundly with adequate nutritional substances and increased extra-oxygen concentrations (diluted into water droplets), giving to the plants optimum growth and maturation conditions. For the long-term growing periods in the deeper canals $(70 \mathrm{~cm})$, the mist system could not 


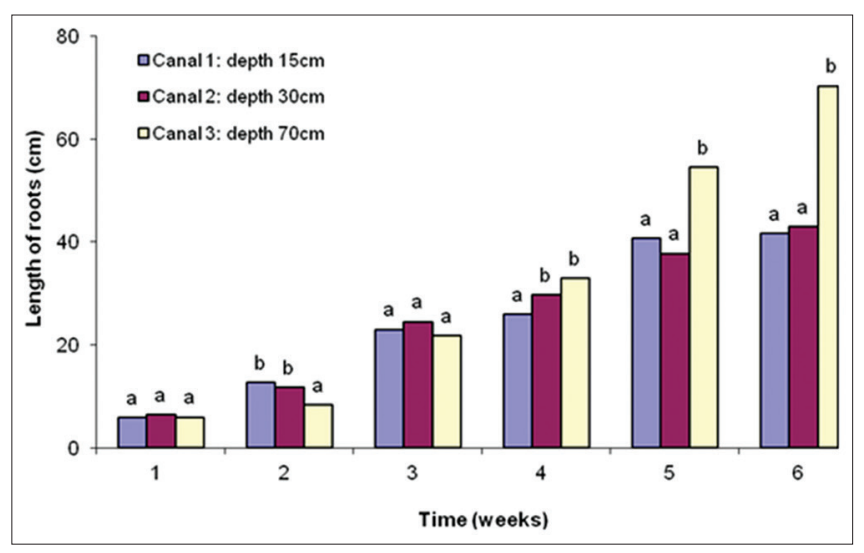

Fig 4. Mean root length of aeroponically cultivated basil plants during cultivation season, in relation to the available root-zone volume.

effectively enforce the nutrient droplets onto the dense root system due to the greater distance between the plant roots and the mist sprayers. This explains the need for increased root growth (longer and heavier roots) for the plants cultivated in deeper $(70 \mathrm{~cm})$ canals, in order to overcome the inadequate long-distance nutrient solution injection (Fig. 4). There is luck of modern studyes on the impact of the absorption of the nutrients by the roots of aeroponically growing plants. Barak et al. (1996) experimenting with aeroponic cranberries showed that water and nutrient uptake rates over time under varying conditions, displayed diurnal variations between ion concentration and uptake. The investigation of the effect of plant position on root development and vegetative growth in aeroponic lettuce revealed that the development of the plants was strongly affected by their position on the panel (Repetto et al. 1994). It is also revealed that the different root development is affected by the distance from the ground or by the distance between the plants and the mist sprayer.

In aeroponics, various root zone volume dimensions have been used for the development of the roots. Tierno et al. (2013), used an aeroponic cultivation system for potato with dimensions $1 \mathrm{~m}$ height $\mathrm{x} 0.8 \mathrm{~m}$ width $\mathrm{x} 1 \mathrm{~m}$ depth. Also Farran et al. (2006), used another aeroponic system for potato with $0.85 \mathrm{~m}$ depth. Different root zone volume dimentions were used in other experiments with different plant species. The dimensions of the aeroponic system for Kamies et al. (2010), were $0.4 \times 0.3 \mathrm{~m}$ and $0.4 \mathrm{~m}$ high for Xerophyta viscose, and for Martin-Laurent et al. (1997) were $2.20 \mathrm{~m} \times 1.50 \mathrm{~m} \times 0.50 \mathrm{~m}$ for Acacia mangium.

Root zone temperature, root zone $\mathrm{CO}_{2}$ treatment and their impact on root development, nutrient uptake and product yield have been on the focuw of aeroponics (Lay et all. 2002, He et al. 2010). High dissolved oxygen was substantial for root formation and growth in aerohydroponic rooting of Fictis benjamins L. cuttings (Soffer and Burger, 1988). Recently an alternative production system for high-value root crops was developed for the herbal and phytopharmaceutical industries, allowing the producers to precisely control root zone nutrient and water regimes (Hayden, 2014). The continuous contact of the roots with the atmospheric oxygen and the increased oxygen concentrations diluted into nutrient solution misting droplets, strongly stimulated root metabolism and nutrient uptake (Stoner, 1983). In contrast, the root environment in plants grown hydroponically provides significantly lower root aeration (Soffer and burger, 1988). In aeroponics moreover, the intermitted injection of nutrient solution (decreasies the temperature of the root environment) and affects advantageously the growing of plants in the tropical and subtropical high temperature regions (Lee, 1993, He et al., 2013).

The temperature of the root zone affects root development and nutrient uptake (Sattelmacher et al. 1990; Stolzfus et al. 1998; Tan et al., 2002). Extreme heights or lows of root temperature have a negative impact on root morphology, development, nutrient absorption, inhibiting plant growth and yield (Tan et al, 2002; Nagasuga et al., 2011). The present experimental system, the «Automated Aeroponic Plant Growing System» controls the root zone atmosphere temperature into the root growth chambers or vessels, by monitoring the temperature of nutrient solution sprayed to the roots, offering optimum root growth conditions in real time.

The world market for natural plant products has been rapidly growing over the past 20 years, demanding high quality, uniformity and safety of the products. Greenhouse hydroponic and especially aeroponic cultivation systems, provide the growers with high controlled environmental and agro technical conditions to allow improved quality, purity, consistency and superior product quality on a commercial basis(Stewart and Lovvet-Doust, 2003; Hayden, 2006).

\section{Total chlorophylls and gas exchange parameters}

The results from table I show that the concentration of total leaf chlorophylls strongly decreased (twice) in plants grown under high root zone volume $(70 \mathrm{~cm}$ depth canals), possibly due to inadequate nutrition rates. The reduction of total chlorophyll content, associated strongly with decreased rates of net assimilation characteristics, ie. net photosynthesis rate, leaf transpiration rate and stomatal conductance (Table I). Limited plant growth is strongly associated with the reduction in chlorophyll content and leaf photosynthetic characteristics (Bettman et all, 2006). Moreover, the different irrigation applications used in hydroponically grown gerbera plants affected the photosynthetic capacity of the examined gerbera cultivars (Syros et al., 2004). Decreasing water and nutrients in the root area enhanced the stomatal closure and the reduction 
Table 1: Impact of the available root-zone volume on leaf physiological parameters and chlorophyll content of the leaves of basil plants, cultivated aeroponically

\begin{tabular}{|c|c|c|c|c|}
\hline $\begin{array}{l}\text { Treatments } \\
\text { Depth }\end{array}$ & 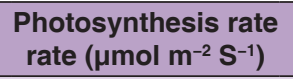 & $\begin{array}{l}\text { Transpiration rate } \\
\text { rate }\left(\mathrm{mmol} \mathrm{m}^{-2} \mathrm{~S}^{-1}\right)\end{array}$ & $\begin{array}{c}\text { Stomatal conductance } \\
\left(\mathrm{mol} \mathrm{m}^{-2} \mathrm{~S}^{-1}\right)\end{array}$ & $\begin{array}{l}\text { Chlorophyll content } \\
\text { ( } \mu \text { gr Chl/gr D.W.) }\end{array}$ \\
\hline $15 \mathrm{~cm}$ & $10.3 \mathrm{~b}$ & $2.7 \mathrm{~b}$ & $0.1 \mathrm{~b}$ & $2725 \mathrm{~b}$ \\
\hline $30 \mathrm{~cm}$ & $10.1 \mathrm{~b}$ & $2.5 \mathrm{~b}$ & $0.1 \mathrm{~b}$ & $2945 b$ \\
\hline $70 \mathrm{~cm}$ & $7.7 \mathrm{a}$ & $1.8 \mathrm{a}$ & $0.1 \mathrm{a}$ & $1384 \mathrm{a}$ \\
\hline
\end{tabular}

of $\mathrm{CO}_{2}$ assimilation as shown from a number of field grown species (Shone and Flood, 1980 and Issa et al., 2001).

\section{Total phenolics}

The variation of the available root zone volume did not affect significantly the concentration of total phenolics for the different treatments (Fig. 5). However, during the growing season the content of total phenolics increased in all cases, achieving maximum values at the end of maturation period. Different leafy vegetables/herbs (among then basil plants) and fruit crops grown in aeroponic systems showed a higher yield and phenolics content, compared to those grown in the soil (Chandra et al. 2014). Flanigan and Niemeyer (2014) studying eight purple basil varieties, reported that cultivar did not affect total phenolic content in basil plants grown in pots with Ferti-lome soil. Our previous studies with hydroponically grown red beets subjected to nitrogen stress, showed strong accumulation of high amounts of total phenolics and betacyanins (Salachas et al. 2012). This was also confirmed from other studies with aeroponically grown lettuce plants under $\mathrm{N}$ stress (data not shown).

A survey of agricultural technologies influencing the biosynthesis and accumulation of phenolic compounds in crop plants, including observations on the effects of light, temperature, mineral nutrition management, water management, grafting, elevated atmospheric CO2, stimulating agents and plant activators have been made by Treuetter (2010). Although the existing experimental evidence is limiting, aeroponics by enabling rapid and efficient manipulation of the nutrients uptake, should be used for the large scale production of such health promoting plant metabolites.

\section{Isolation and analysis of essential oils}

Essential oils were isolated and their chemical composition was determined at the end of the cultivation period when basil plants reached full bloom (Fig. 6, Table II). No significant differences were observed for plants grown in different root zone volumes (tunnel depths 15,30 , and $70 \mathrm{~cm}$ ), with the concentration being $0.83 \%$, $0.79 \%$ and $0.80 \%$, respectively. All three samples were characterized by high content of linalool, with the highest in canal $2(67.02 \%)$, followed by canal $3(66.58 \%)$ and canal 1 (63.85\%), in agreement with the findings of Nurzyńska-Wierdak et al. (2013) where the content of linalool was determined at 57-75\% and with Marotti et al.

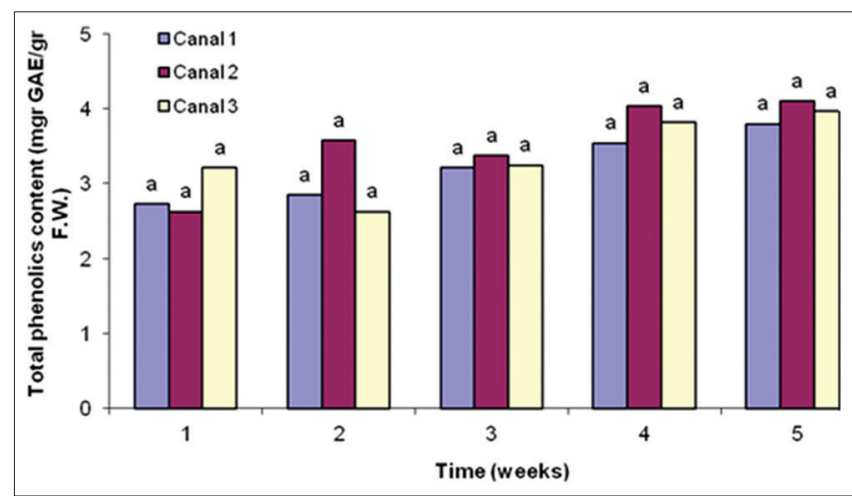

Fig 5. Impact of the available root-zone volume on the leaf total phenolics content of basil plants, cultivated aeroponically. Canal 1: depth $15 \mathrm{~cm}$. Canal 2: deptht $30 \mathrm{~cm}$. Canal 3: deptht $70 \mathrm{~cm}$.

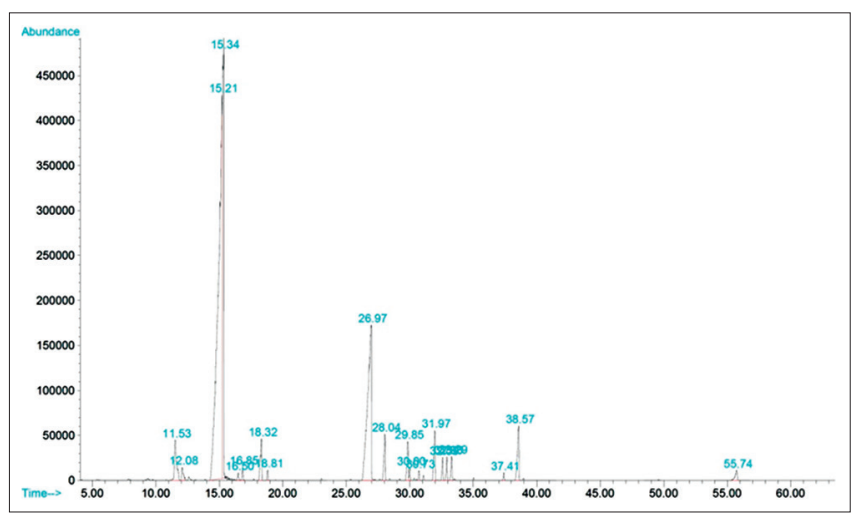

Fig 6. Typical GC profile of essential oil from cultivar in canal 1: height $15 \mathrm{~cm}$, width $70 \mathrm{~cm}$.

(1996) where the content was 41-77\%. Isoeugenol was the component with the next highest percentage (11-18\%), followed by 1,8-cineole (2-4\%), 10-epi- $\alpha$-cadinol (2-3\%) and germacrene D (2-3\%) (Table II). In addition, the highly toxic methyl-chavicol was not identified by our method.

The essential oil isolated elsewhere from basil plants (less than $1 \%$ ) is of complex and variable composition with the major components been linalool, estragole, methyl cinnamate, eugenol, 1,8 cineole (Juliani and Simon, 2002; Lee et al., 2005), methyl chavicol, neral and caryophyllene oxide (Pirbalouti, et al., 2013). Linallol, 1,8 cineole, estragole and to a lesser degree eugenol are the most important aroma compounds (Makri \& Kintzios, 2008). Some of the components show strong biological activity: linalool shows anti-inflammatory, antibacterial, antiviral, antifungal and relaxant properties (Silva et al., 2015. Eugenol displays 
Table 2: Chemical Composition (\%) of Basil Cultivar Essential Oils

\begin{tabular}{lclccc}
\hline S. No & Rt & Components & \multicolumn{3}{c}{$\%$} \\
\cline { 3 - 5 } & & & Canal 1 & Canal 2 & Canal 3 \\
\hline 1. & 11,54 & Eucalyptol (1,8-cineole) & 2,80 & 3,42 & 3,92 \\
2. & 12,10 & (E)-ocimene & 0,65 & 0,83 & 0,85 \\
3. & 15,34 & Linalool & 63,85 & 67,02 & 66,58 \\
4. & 16,49 & (E)-epoxy-ocimene & 0,24 & 0,29 & 0,31 \\
5. & 16,84 & Camphor & 0,37 & 0,49 & 0,45 \\
6. & 18,32 & Terpine-4-ol & 1,79 & 1,96 & 1,95 \\
7. & 18,81 & Camphene & 0,29 & 0,26 & 0,33 \\
8. & 26,89 & (Z)-Isoeugenol & 18,11 & 13,13 & 11,86 \\
9. & 28,04 & B-elemene & 1,81 & 2,20 & 2,26 \\
10. & 29,86 & (E)-á-bergamotene & 1,56 & 1,73 & 1,73 \\
11. & 30,01 & á-guaiene & 0,35 & 0,40 & 0,40 \\
12. & 30,74 & (Z)-á-bisabolene & 0,29 & 0,39 & 0,48 \\
13. & 31,11 & á -copaene & nd & nd & 0,21 \\
14. & 31,98 & Germacrene D & 2,02 & 2,38 & 2,70 \\
15. & 32,60 & Bicyclogermacrene & 0,81 & 0,90 & 1,07 \\
16. & 32,94 & Caryophyllene & 0,73 & 0,83 & 0,83 \\
17. & 33,31 & ã-cadinene & 0,82 & 0,97 & 1,09 \\
18. & 37,41 & $\alpha$-cadinene & 0,21 & 0,20 & 0,22 \\
19. & 38,57 & 10-epi-á-cadinol & 2,69 & 2,61 & 2,76 \\
\hline
\end{tabular}

ND: Not Detected, ${ }^{*}$ Canal 1: depth $15 \mathrm{~cm}$, Canal 2: depth $30 \mathrm{~cm}$, Canal 3: depth $70 \mathrm{~cm}$

antioxidant and antimicrobial activity while 1,8 cineole has antiseptic and anesthetic effects (Nurzyńska-Wierdak et al, 2013). The extracts of many herb spices, especially from the Lamiaceae family, showed strong antioxidant activity (Hirasa \& Takemasa, 1998). Ocimum basilicum extracts display potent antioxidant properties with phenolic acids considered being the strongest antioxidants. The high antioxidant capacity of basil has been primarily attributed to the most prevalent phenolic acid in basil rosmarinic acid and secondary to caffeic, p-coumaric, ferulic, syringic and vanillic acids (Chen \& Ho, 1997, Petersen \& Simmonds 2003, Makri \& Kintzios, 2008, Lee \& Scagel, 2009).

The product quality of basil plants i.e. the total phenolics content and the accumulation and composition of the essential oils are influenced by genetic, ontogenic, environmental and agrotechnical factors (Makri \& Kintzios, 2008; Sgherri et al., 2010; Ipec et all. 2012). Optimal plant fertilization is of great importance (Sifola and Barbieri, 2006; Nurzynska-Wierdak et al., 2013). The composition of the essential oils is also affected by the location: in Egyptian sweet basil the prevalent composers are linalool and estragole, in Israel sweet basil are linalool, estragole and eugenol, in Italian sweet basil are eugenol, methyleugenol, eucalyptol and linalool and in Spanish sweet basil are linalool and eugenol (Calín-Sánchez et al., 2012).

Our above findings suggest that the nutritional quality of basil plants grown aeroponically is superior, in comparison with previous cultivation methods.

\section{CONCLUSIONS}

We demonstrate that the available root zone volume is an important factor for plants grown in aeroponic systems. Misting the nutrient solution under high pressure directly and closer onto the surface of the roots apparently enforced the profoundly uptake of adequate nutrients. In addition, the absorption of the extra-oxygen (diluted into water micro droplets absorbed by the roots) increase nutrient uptak and root metabolism, providing optimum root growth conditions. In contrast, a larger distance between misting sprayers and roots deteriorated or restricted root access to the water micro droplets, resulting in decreasing nutrients availability and absorbance. In this case, plants are enforced to compensate by increasing root surface area and weight. To resolve this problem, numerous inventions have been developed to facilitate and improve nutrient spraying and misting in aeroponics (Hikosaka et al. 2014). There is a need for the development of more high-pressure commercial aeroponic techniques, where the mist should be generated by high-pressure pumps and hydro-atomized sprays in order to cover large areas of roots. More experimental evidence is required in order to determine the exact agrotechnical and physicochemical parameters optimizing root growth environment in aeroponics. Basil plants grown aeroponically found to be of superior nutritional quality characteristics.

\section{ACKNOWLEDGMENTS}

This research has been co-financed by the European Union (European Social Fund - ESF) and Greek national funds through the Operational Program "Education and Lifelong Learning" of the National Strategic Reference Framework (NSRF) - Research Funding Program: ARCHIMEDES III. Investing in knowledge society through the European Social Fund.

\section{AUTHOR CONTRIBUTIONS}

G.S. was the main contributor in designing the research and preparing the manuscript. D. S., contributed to research planning and all intermittent steps until manuscript preparation. P. A. T. contributed in the design and the research for the isolation and analysis of the essential oils. K. A. was involved in carrying out experiments and collecting data and G. K. was involved in data analysis, and manuscript writing. All five authors approved of the manuscript for publication and take public responsibility for the content, while declaring no conflict of interest associated with any aspect of this manuscript (financial or other). 


\section{REFERENCES}

Barak, P., J. D. Smith, A. R. Krueger and L. A. Peterson. 1996. Measurement of short-term nutrient uptake rates in cranberry by Aeroponics. Plant Cell. Environ. 19(2): 237-242.

Bettmann, G. T., H. H. Ratnayaka, W. T. Molin and T. M. Sterling. 2006. Physiological and antioxidant responses of cotton and spurred anoda (Anoda cristata) under nitrogen deficiency. Weed Sci. 54: 641-650.

Burgess, T., J. McComb and G. Hardy. 1998. Influence of low oxygen levels in aeroponics chambers on aucalypt roots infected with Phytophthora cinnamomi. Plant Dis. 82: 368-373.

Calín-Sánchez, Á., K. Lech, A. Szumny, A. Figiel and Á. A. CarbonellBarrachina. 2012. Volatile composition of sweet basil essential oil (Ocimum basilicum L.) as affected by drying method. Food Res. Int. 48: 217-225.

Chandra, S., S. Khan, B. Avula, H. Lata, M. H. Yang, M. A. Elsohly and I. A. Khan. 2014. Assessment of total phenolic and flavonoid content, antioxidant properties, and yield of aeroponically and conventionally grown leafy vegetables and fruit crops: A comparative study. Evid. Based Compl. Altern. Med. 2014: Article ID:253875, 9.

Chen, J. H. and C. T. Hou. 1997. Antioxidant activities of caffeic acid its relared hydroxycinnamic acid compounds. J. Agric. Food Chem. 45: 2374-2378.

Chiipanthenga, M., M. Maliro, P. Demo and J. Njoloma. 2012. Potential of aeroponics system in the production of quality potato (Solanum tuberosum I.) seed in developing countries. Afr. J. Biotechnol. 11(17): 3993-3999.

Issa, M., G. Ouzounidou, H. Maloupa and H. I. A. Constantinidou. 2001. Seasonal and diurnal photosynthetic responses of two gerbera cultivars to different substrates and heating systems. Sci. Hortic. 88(3): 215-234.

Farran, I. and A. M. Mingo-Castel. 2006. Potato minituber production using Aeroponics: Effect of plant density and harvesting intervals. Am. J. Pot. Res. 83: 47-53.

Flanigan, P. M., E. D. Niemeyer. 2014. Effect of cultivar on phenolic levels, anthocyanin composition, and antioxidant properties in purple basil (Ocimum basilicum L.). Food Chem. 164: 518-526.

Grayer, R. G., G. C. Kite, F. J. Goldstone, S. E. Bryan, A. Paton, and E. Putievsky. 1996. Infraspecific taxonomy and essential oil chemotypes in basil, Ocimum basilicum. Phytochem. 43: 10331039.

Hayden, A. L. 2014. Aeroponic and hydroponic systems for medicinal herb, rhizome and root crops. Hortic. Sci. 41(3): 536-538.

He, J., T. Austin and S. K. Lee. 2010. Effects of elevated root zone $\mathrm{CO} 2$ and air temperature on photosynthetic gas exchange, nit rate uptake, and total reduced nitrogen content in aeroponically grown lettuce plants. J. Exp. Bot. Sep. 61(14): 3959-3969.

He, J., L. Qin and S. K. Lee. 2013. Root-zone CO2 and root-zone temperature effects on photosynthesis and nitrogen metabolism of aeroponically grown lettuce (Lactuca sativa L.) in the tropics. Photosynthetica. 51(3): 330-340.

Hirasa, K. and M. Takemasa. 1998. Spice Science and Technology, Marcel Dekker, New York.

Hikosaka, Y., M. Kanechi and Y. Uno. 2014. A novel aeroponic technique using dry-fog spray fertigation to grow leaf lettuce (Lactuca sativa L. var. Crispa) with water-saving hydroponics. Adv. Hortic. Sci. 28(4): 184-189.

İpek, A., B. Gürbüz, M. U. Bingöl, F. Geven, G. Akgül, P. R. Afshar and B. Coşge. 2012. Comparison of essential oil components of wild and field grown Salvia cryptantha Montbert \& Aucher ex
Benthan, in Turkey. Turk. J. Agric. For. 36: 668-672.

Juliani, H. R. and J. E. Simon. 2002. Antioxidant activity of basil. In: Janic, J. and A. Whipkey, (Eds.), Trends in New Crops and New Uses, ASHS Press, Alexandria, VA, Pp. 575-579.

Kamies, R., M. S. Rafudeen and J. Farrant. 2010. The use of aeroponics to investigate antioxidant activity in the roots of Xerophyta viscose. Plant Growth Regul. 62: 203-211.

Kiferle, C., R. Maggini and A. Pardossi. 2013. Influence of nitrogen nutrition on growth and accumulation of rosmarinic acid in sweet basil (Ocimum basilicum L.) grown in hydroponic culture. Aust. J. Crop Sci. 7(3): 321-327.

Lee, J. and C. F. Scagel. 2009. Chicoric acid found in basil (Ocimum basilicum L.) leaves. Food Chem. 115: 650-656.

Lay, P. T., J. He and K. L. Sing. 2002. Effects of root-zone temperature on the root development and nutrient uptake of Lactuca sativa $\mathrm{L}$. "Panama" grown in an Aeroponic system in the tropics. J. Plant Nutr 25(2): 297-314.

Lee, S. K. 1993. Aeroponic system as possible alternative for crop production in Singapore. Common Wealth Agric. Digest. 3(1): 1-14.

Lee, S. J., K. Umano, T. Shibamoto and K. G. Lee. 2005. Identification of volatile components in basil (Ocimumu basilicum L.) and thyme leaves (Thymus vulgaris L.) and their antioxidant properties. Food Chem. 91(1): 131-137.

Loughrin, L. H. and M. J. Kasperbauer. Light reflected from colored mulches affects aroma and phenolic content of sweer basil (Ocimumu basilicum L.) Leaves. J. Agric. Food Chem. 49: 13311335.

Maboko, M. M. and C. P. Du Plooy. 2013. High-plant density planting of basil (Ocimum basilicum) during summer/fall growth season improves yield in a closed hydroponic system. Acta Agric. Scan. Sec B Soil Plant Sci. 63(8): 748-752.

Makri, O. and S. Kintzios. 2008. Ocimum sp. (basil): Botany cultivation, pharmaceutical properties and biotechnology. J. Herbs Spices Med. Plants. 13: 123-150.

Martin-Laurent, F., S. K. Lee, F. Y. Tham, J. He, H. G. Deim and P. Durand. 1997. A new approach to enhance growth and nodulation of Acacia mangium through aeroponic culture. Biol. Fertility Soils. 25: 7-12.

Mazza, G., L. Fukumoto, P. Delaquis, B. Girard and B. Ewert. 1999. Anthocyanins, phenolics, and color of cabernet France, Merlot, and Pinot Noir wines from British Columbia. J. Agric. Food Chem. 47(10): 4009-4017.

Nagasuga, K., M. Murai-Hatano and T. Kuwagata. 2011. Effects of low root temperature on dry matter production and root water uptake in rice plants. Plant Prod. Sci. 14(1): 22-29.

Nurzyńska-Wierdak, R., B. Borowski, K. Dzida, G. Zawiślak and R. Kowalski. 2013. Essential oil composition of sweet basil cultivars as affected by nitrogen and potassium fertilization. Turk. J. Agric. Forest. 37: 427-436.

Petersen, M. and M. S. J. Simmonds. 2003. Rosmarinic acid Phytochemistry. 62: 121-125.

Peterson, L. A. and A. R. Krueger. 1988. An intermittent Aeroponics system. Crop. Sci. 28: 712-713.

Pirbalouti, A. G., E. Mahdad and L. Craker. 2013. Effects of drying methods on qualitative and quantitative properties of essential oil of two basil landraces. Food Chem. 141(3): 2440-2449.

Putievsky, E. and B. Galambosi. 1999. Production systems of sweet basil. In: Hiltunen, R. and Y. Holm, (Eds.), Basil: The Genus Ocimum, Vol. 10. Harwood Academic Publishers, Amsterdam, Pp. 39-65.

Repetto, A., M. Cadinu, and S. Leoni 1994. The effect of plant position 
on root development and vegetative growth in aeroponic lettuce. In: Proceedings of the International Symposium on New Cultivation Systems in Greenhouse. ISHS Acta Horticulturae 361, Online Article.

Roosta, H. R. 2014. Comparison of the vegetative growth, ecophysiological characteristics and mineral nutrient content of basil plants in different irrigation ratios of hydroponic: Aquaponic solutions. J. Plant Nutr. 37(11): 1782-1803.

Salahas, G., A. Papasavvas, E. Giannakopoulos, T. Tselios and D. Savvas. 2012. Impact of nitrogen deficiency on biomass production, gas exchange, and betacyanin and total phenol concentrations in red beet (Beta vulgaris L. ssp. Vulgaris) plants. Eur. J. Hortic. Sci. 76(5): 194-200.

Sattelmacher, B., H. Marschner and R. Kühne. 1990. Effects of the temperature of the rooting zone on the growth and development of roots of potato (Solanum tuberosum). Ann. Bot. 65: 27-36.

Sgherri, C., S. Pinzino, C. Cecconami, F. Navari-Izzo and R. Izzo. 2010. Levels of antioxidants and nutraceuticals in basil grown in hydroponivs and soil. Food Chem. 123: 416-422.

Shinano, T., T. T. Lei, T. Kawamukai, M. T. Inoue, T. Koike and T. Tadano. 1996. Dimethylsulfoxide method for the extraction of chlorophylls $a$ and $b$ from the leaves of weat, field bean, dwarf bamboo and oak. Photosynthetica. 32: 409-415.

Sifola, M.I. and G. Barbieri. 2006. Growth, yield, and essential oil content of three cultivars of basil grown under different levels of nitrogen in the field. Sci. Hortic. 108: 408-413.

Silva, V. A., J. P. Sousa, F. Q. S. Guerra, L. B. N. Alves and E. O. Lima. 2015. Antibacterial activity of the monoterpene linalool: Alone and in association with antibiotics against bacteria of clinical importance. Int. J. Pharmacogn. Phytochem. Res. 7(5): 1022-1026.

Simon, J. E., J. Quinn and G. G. Murray. 1990. Basil: A source of essential oils. In: Janick, J. and Simon, J. E. (Eds.), Advances in New Crops. Timber Press, Portland, OR, Pp. 484-489.

Soffer, H. and D. W. Burger. 1988. Effects of dissolved oxygen concentration in aero-hydroponics on the formation and growth of adventitious roots. J. Am. Soc. Hortic. Sci. 113: 218-221.

Shone, M. G. T. and A. V. Flood. 1980. Studies on uptake and loss of water by barley roots in relation to changes in root resistance. J. Exp. Bot. 31(4): 1147-1159.

Stewart, C. L. and L. Lovvet-Doust. 2003. Effect of phosphorus treatment on growth and yield in the medicinal herb Calendula officinalis L. (Standard Pacific) under hydroponic cultivation. Can. J. Plant Sci. 83(3): 611-617.

Stojiljković, J., M. Nikšić, N. Stanišić, Z. Stojiljković and G. Trajkovski. 2015. Antimicrobial activity of sweet basil and thyme against Salmonella enterica serotype enteritidis in egg-based pasta. Arch. Biol. Sci. 67(1): 213-221.

Stoltzfus, R. M., H. G. Taber and A. S. Aiello. 1998. Effect of increasing root-zone temperature on growth and nutrient uptake by 'Gold Star' muskmelon plants. J. Plant Nutr. 21(2): 321-328.

Stoner, R. J. 1983. Aeroponics versus bed and hydroponic propagation. Florists' Rev. 173(1): 4477.

Syros, T., T. Yupsanis, M. Omirou and A. Economou. 2004. Photosynthetic response and peroxidases in relation to water and nutrient deficiency in gerbera. Environ. Exp. Bot. 52(1): 23-31.

Tan, L. P., J. Heand and S. K. Lee. 2002. Effects of root-zone temperature on the root development and nutrient uptake of Lactuca sativa L. 'Panama" grown in Aeroponic system in tropics. J. Plant Nutr. 25(2): 297-314.

Tierno, R., A. Carrasco, E. Ritter and J. I. R. de Galarreta. 2013. Differential growth response and minituber production of three potato cultivars under Aeroponis and greenhouse bed culture. Am. J. Potato Res. 91(4): 346-353.

Treutter, D. 2010. Managing phenol content $s$ in crop plants by phytochemical farming and breeding-visions and constraints. Int. J. Mol. Sci. 11(3): 807-857.

Vieira, R. F. and J. E. Simon. 2006. Chemical characterization of basil (Ocimum spp.) based on volatile oils. Flav. Fragr. J. 21: 214-221.

Walters, K. J. and C. J. Currey. 2015. Hydroponic greenhouse basil production: Comparing systems and cultivars. Hortic. Technol. 25(5): 645-650.

Waltz, L. 1996. The Herbal Encyclopedia. Avaliable from: http://www. wic.net/waltzark/herbenc. htm.

Zhao, X., T. L. Li and Z. P. Sun. 2010. Effects of prolonged root-zone $\mathrm{CO} 2$ treatment on morphological parameter and nutrient uptake of tomato grown in aeroponic system. J. Appl. Bot. Food Q. 83(2): 212-216.

Zobel, R. W., P. Del Tredici and J. G. Torrey. 1976. Method for growing plants aeroponically. Plant Physiol. 57: 344-346. 